\title{
Komunikasi Politik Mohammad Natsir
}

\author{
Roni Tabroni \\ Universitas Sangga Buana YPKP, Bandung \\ roni_tepas@yahoo.com
}

\begin{abstract}
This study aims to reveal aspects of political communication made by $M$. Natsir when formulating, socialize, until the date of the adoption by MPRS integral motion. This study uses qualitative descriptive approach, so as to reveal the fact that more comprehensive. This study has revealed a struggle that is not simply how a motion integral before being accepted and confirmed by parliament. $M$. Natsir when trusted to formulate make the concept of unification of Indonesia in response to the threat of disintegration, he conducted political lobbies are quite long, before finally when dipidatokan no interruptions and obstacles of other MPs. These findings make clear that aspects of political communication becomes very important in reading a historical fact related to the socialization integral motion Natsir.
\end{abstract}

Keywords: Political Communication, M. Natsir, Integral Motion

\section{ABSTRAK}

Penelitian ini bertujuan mengungkap aspek komunikasi politik yang dilakukan oleh $\mathrm{M}$. Natsir ketika merumuskan, mensosialisasikan, hingga diterima dan ditetapkannya mosi integral oleh MPRS. Penelitian ini menggunakan metode kualitatif melalui pendekatan deskriptif, sehingga dapat mengungkap fakta yang lebih komprehensif. Penelitian ini mengungkapkan sebuah fakta perjuangan yang tidak sederhana bagaimana mosi integral sebelum diterima dan ditetapkan oleh parlemen. M. Natsir ketika dipercaya untuk merumuskan membuat konsep penyatuan bangsa Indonesia sebagai jawaban dari ancaman disintegrasi bangsa, beliau melakukan loby-loby politik yang cukup panjang, sebelum akhirnya ketika dipidatokan tidak ada interupsi dan hambatan dari anggota parlemen yang lain. Temuan ini semakin memperjelas bahwa aspek komunikasi politik menjadi sangat penting dalam membaca sebuah fakta historis terkait dengan sosialisasi mosi integral M. Natsir.

Kata Kunci : Komunikasi Politik, M. Natsir, Mosi Integral

\section{Pendahuluan}

Salah satu di antara sekian banyak tokoh nasional yang memiliki jasa besar pada bangsa Indonesia adalah M. Natsir. Sosok yang pernah menjadi Perdana Menteri Indonesia ini mencetuskan sebuah gagasan penting yang kemudian dikenal dengan Negara Kesatuan Republik Indonesia (NKRI) yang hingga kini dipegang teguh dan harga mati bagi bangsa Indonesia. Jasa besar M. Natsir untuk menghindari distintegrasi 
bangsa karena ulah Belanda untuk menciptakan Republik Indonesia Serikat (RIS) ini dianggap sebagai langkah cerdas dalam menyelamatkan keutuhan bangsa.

Apresiasi patut diberikan kepada M. Natsir atas jasanya yang sangat penting itu. Bahkan Eep Saefulloh Fatah di HU Republika (20 Januari 1995, H. 9) mengibaratkan bahwa bagai sayur tanpa garam bila membicarakan Indonesia tanpa menyebut sosok M. Natsir. Adalah mustahil membuat peta pemikiran cendikiawan muslim Indonesia dengan mengabaikan pemikiran Natsir. Mustahil pula merekontruksikan sejarah politik Indonesia dengan menghapus peranan Natsir di dalamnya. Mustahil pula membuat daftar nama para negarawan yang mampu bertindak konstitusional, demokratis, dan terhormat, yang jumlahnya sedikit, dengan menyingkirkan nama besar Natsir.

Mohammad Natsir merupakan sosok langka. Natsir telah lulus menjadi tokoh politik dan negarawan sekaligus. Dia diberi kesempatan oleh sejarah untuk mempraktikkan formula demokrasinya untuk membawa umat tampil menjadi warga negara.

Natsir orangnya tergolong puritan. Tapi kadang kala orang yang lurus bukan berarti tidak menarik. M. Natsir adalah orang yang sanggup menyatukan kata-kata dan perbuatan. Karena Indonesia sekarang seakan-akan hidup di sebuah "lingkaran syetan" yang tak terputus: regenerasi kepemimpinan terjadi, tapi birokrasi dan politik yang bersih, kesejahteraan sosial yang lebih baik, terlalu jauh dari jangkauan. Natsir seolah-olah mewakili sosok yang berada di luar lingkaran itu. Ia bersih, tajam, konsisten dengan sikap yang diambil.

Dalam hidupnya yang cukup panjang, dibalik kelemahlembutannya, ada kegigihan seorang yang mempertahankan sikap. Ada keteladanan yang sampai kini membuat kita sadar bahwa bertahan dengan sikap yang bersih, konsisten, dan bersahaja itu bukan mustahil meskipun penuh tantangan. Hari-hari belakangan ini kita merasa teladan hidup seperti itu begitu jauh, bahkan sangat jauh.

Kalau menengok ke belakang, Natsir bukanlah lahir dari golongan orang tua terpandang. Orang tuanya merupakan pegawai yang pendapatanya kecil. Namun, kalaupun begitu, Natsir tidak merasa minder bahkan di sekolahnyapun Natsir tergolong anak yang cerdas. Dalam usia yang relatif muda Natsir sudah menguasai banyak bahasa. Bahasa Belanda, Inggris, Perancis, Latin dan bahasa Arab.

Natsir juga merupakan putra Indonesia yang dikenal sebagai birokrat, politisi dan juga Da’i ternama. Sebagai birokrat, Natsir pernah menduduki jabatan penting sebagai menteri penerangan dalam kabinet 
Sjahrir dan perdana menteri pertama Negara Kesatuan Republik Indonesia pada masa pemerintahan Soekarno. Sebagai politisi, Natsir pernah menduduki jabatan puncak partai Islam terbesar pada zamannya, yaitu Masyumi, dan pernah memperjuangkan Islam sebagai dasar negara. Adapun seorang Da'i ternama, Natsir pernah menduduki jabatan sebagai wakil Presiden Alam Islami sekaligus juga sebagai tokoh puncak Rabithah Alam Islami, serta menjadi ketua Dewan Dakwah Islamiyah Indonesia sejak 1967 sampai wafatnya 1993.

Hingga tiba saatnya, Mohammad Natsir melihat bahwa negaranya pasca perjanjian Meja Bundar yang menyepakati dibentuknya Republik Indonesia Serikat (RIS) adalah membahayakan bagi bangsa dan negara. Natsir melakukan inisiatif mosi integralnya. Mosi ini dia usulkan melalui pidatonya dalam sidang parlemen RIS pada 3 April 1950.

Saat itu negeri dalam keadaan terpecah-pecah menjadi negara serikat sebagaimana yang harapkan penjajah Belanda, Natsir dengan pikiran yang brilian mencoba menyelamatkannya. Mosinya yang kemudian dikenal dengan Mosi Integral Natsir merangkai kembali Indonesia sebagai negara kesatuan yang utuh yang telah berjalan lebih 50 tahun lamanya, namun dalam beberapa tahun terakhir terancam tercabik-cabik. Berbekal Mosi Integral Natsir inilah Sukarno meresmikan kembali Indonesia sebagai negara kesatuan pada 17 Agustus 1950. Peristiwa ini adalah proklamasi kedua republik ini setelah proklamasi 17 Agustus 1945. Berkat jasanya ini Sukarno kemudian mengangkatnya sebagai perdana mentri, namun karena sifat lurusnya ia kemudian mengundurkan diri dari jabatan itu.

Bagi bangsa Indonesia, mosi integral bukan hanya konsep atau produk pemikiran biasa, sebab mosi integral secara terang telah menyelamatkan Negara Indonesia dari ancaman perpecahan. Pentingnya mosi integral ini semakin diakui oleh Negara ini ketika pada tahun 2008 Mohammad Natsir diberi gelar pahlawan oleh Presiden RI Susilo Bambang Yudoyono (SBY).

Sebagai konsep besar, mosi integral tentu saja membutuhkan kemampuan khusus bagi penggagasnya yaitu M. Natsir untuk meyakinkan berbagai pihak, khususnya anggota parlemen untuk menyetujuinya. Di sini kemampuan mengkomunikasikan menjadi sama pentingnya dengan konsepnya itu sendiri. Lahirnya NKRI akhirnya tidak hanya dapat dikaji dari sisi politik semata, tetapi dari sisi komunikasinya. Di sini konsep komunikasi politik menjadi relefan sebab sebuah pemikiran politik memerlukan kemampuan komunikasi untuk menjadikannya diterima oleh lembaga politik yaitu anggota parlemen 
pada saat itu. Posisi mosi integral sendiri dalam konteks komunikasi politik menjadi pesan politik. Akhirnya mosi integral M. Natsir sebagai pesan dalam komunikasi politik M. Natsir menjadi penting untuk diteliti, sekaligus tentang cara mengkomunikasikannya.

Penelitian ini menggunakan pendekatan kualitatif. Menurut Bognan dan Taylor (dalam Moleong, 2000:3), "metode kualitatif" sebagai prosedur penelitian yang menghasilkan data deskriptif berupa kata-kata tertulis atau lisan dari orang-orang dan prilaku yang dapat diamati. Menurut mereka, pendekatan ini diarahkan pada latar dan individu tersebut secara holistik (utuh). Jadi, dalam hal ini tidak boleh mengisolasikan individu atau organisasi ke dalam variabel atau hipotesis. Tetapi perlu memandangnya sebagai bagian dari satu kesatuan yang utuh.

Penelitian deskriptif juga bersifat pemaparan dan bertujuan untuk memperoleh gambaran (deskripsi) lengkap tentang keberadaan komunitas tertentu atau mengenai gejala sosial tertentu, atau peristiwa tertentu yang terjadi dalam masyarakat. Pada penelitian tipe ini, peneliti biasanya sudah memperoleh data awal atau mempunyai pengetahuan awal.

Menurut Hyman (dalam Tan, 1997: 42), penelitian deskriptif berjutuan menggambarkan sifat-sifat, keadaan, gejala suatu individu atau kelompok tertentu atau untuk menentukan frekuensi adanya hubungan tertentu antara suatu gejala dengan gejala lain dalam masyarakat. Sedangkan menurut Rusidi (1999:18), penelitian deskriptif bermaksud menggambarkan fenomena empirik yang disertai dengan penafsiranpenafsirannya dengan tujuan memperoleh gambaran setepat realitanya.

Selain pemaparan tersebut, Kirk dan Miller juga mendefinisikan bahwa penelitian kualitatif adalah tradisi tertentu dalam ilmu pengetahuan sosial yang secara fundamental tergantung pada pengamatan pada manusia dalam kawasannya sendiri dan berhubungan dengan orang-orang tersebut dalam bahasanya dan dalam peristilahannya (Moleong, 2003:3)

Kajian ini menggunakan sumber data primer dan sekunder, karena sosok tokoh yang dikaji pada studi ini telah wafat, maka data primer akan diperoleh melalui kajian terhadap karya-karya M. Natsir yang masih beredar, antara lain sebagai berikut: Capita Selekta, Agama dan Negara, Islam sebagai Dasar Negara, Kebudayaan Islam dalam Perspektif Sejarah, Fiqhud Da'wah, dan tulisan-tulisan lepas yang terdapat dalam majalah-majalah terutama majalah Media Dakwah.

Sedangkan data sekunder diperoleh dari tulisan-tulisan tentang Natsir, penerbitan-penerbitan media massa umum, hasil-hasil studi 
berupa Skripsi, Tesis, dan Disertasi para sajana, jurnal, buku-buku, makalah serta laporan penelitian lain yang telah diterbitkan maupun yang tidak diterbitkan. Disamping yang diperoleh dari proses tersebut, Penulis akan melakukan wawancara dengan kerabat, tokoh Masyumi (yang pernah se zaman) lain yang hari ini masih ada dan dipandang relevan dengan topik-topik termaksud.

Sumber data utama dalam penelitian kualitatif menurut Lofland (dalam Moleong 2000:112), adalah kata-kata dan tindakan. Jadi data diperoleh dari sumber data yang dapat memberikan informasi (informan). Selain kata-kata dan tindakan sebagai sumber data utama juga ada sumber data lain, yaitu sumber data tertulis, seperti buku-buku, arsip, dokumen organisasi dan pribadi, surat kabar, internet, dan lain sebagainya.

Karena pemilihan sumber data bersifat purposif, maka sumber data ditentukan sesuai kebutuhan untuk memenuhi kecukupan data. Sumber data itu paling tidak memenuhi beberapa kriteria terkait dengan tema dalam penelitian ini, seperti pengurus Dewan Dakwah Islam Indonesia (DDII).

Jadi jumlah sumber data sendiri tidak ditentukan berapa banyaknya, namun pemilihan ini dilakukan untuk memenuhi data yang dibutuhkan. Selama data belum cukup pemilihan sumber data terus dilakukan. Bahkan jika masih ada informasi yang belum jelas atau ada yang lupa ditanyakan, maka sumber data yang sama bisa di cross cek kembali untuk memperjelas informasi yang sudah diberikan atau menambahkan informasi yang belum disampaikan. Setelah data dianggap cukup untuk memenuhi kebutuhan penelitian ini maka secara otomatis penelusuran sumber data pun dihentikan.

Teknik pengumpulan data dilakukan dalam upaya memperoleh data yang diharapkan dan otentik, dengan menggunakan alat sehingga data yang diperoleh sesuai dengan apa yang dimaksud dalam penelitian, untuk mencapai maksud tersebut maka teknik pengumpulan data dilakukan dengan cara studi literature, seperti mengumpulkan karya-karya M. Natsir, baik karya tulis maupun karya lainnya. Kemudian mengumpulkan dan menganalisis berbagai pemberitaan dan dekumen lainnya baik majalah, journal maupun media massa lainnya yang terkait dengan penelitian ini. Selain itu, peneliti juga mempelajari pendapat para tokoh intelektual dan cendikiawan tentang pengertian Mosi Integral yang tersebar dalam berbagai dekumentasi.

Penelitian ini dibatasi hanya pada pengkajian sepak terjang $\mathrm{M}$. Natsir dalam memperjuangkan sebuah konsep yang dikenal dengan nama 
"Mosi Integral Natsir" yang disampaikannya pada 3 April 1950. Sedangkan lokasi penelitian dilakukan di di DDII Jawa Barat. Diasumsikan, Jawa Barat sebagai salah satu basis Masyumi yang dalam Pemilu 1955 memperoleh suara terbesar, dan secara lokasi relatif dekat dengan Pusat DDII di Jakarta. Selain itu, kantor DDII Jawa Barat dianggap memadai untuk menggali data-data untuk atau dekumentasidekumentasi terkait dengan penelitian ini. Termasuk para narasumber adalah mereka yang cukup kompeten di bidangnya sehingga dapat memberikan data dan informasi sesuai kebutuhan penelitian.

\section{Mosi Integral M. Natsir}

Dari sekian banyak kontrbusi M. Natsir terhadap bangsa Indonesia ini, mosi integral merupakan buah pemikiran yang paling popular sebab dianggap telah melahirkan bangsa Indonesia yang kedua kali. M. Natsir telah berjasa secara internal kepada Masyumi sebagai Partai di mana dirinya aktif. Di bawah kepemimpinanya Masyumi semakin disegani partai lain. Selain itu, posisi sebagai ulama besar, M. Natsir juga telah melahirkan buah pemikiran yang sangat banyak. Selain bahan bacaan terkait dengan kebangsaan, juga ajaran berdakwah bagi para kader dan ummat Islam yang sangat penting. Fikhud Dakwah telah menjadi pelajaran berharga dan dijadikan buku ajar pengkaderan bukan hanya di dalam negeri tetapi juga di Negeri Jiran.

Namun, dari sekian prinsip penting yang perlu ditauladani dari M. Natsir memang mosi integral telah mengantarkannya menjadi pahlawan nasional. Kendati tidak mudah, namun penganugerahan pahlawan kepada M. Natsir semakin membuktikan bahwa mosi integral merupakan kontribusi amat penting terhadap bangsa ini.

Karenanya, para ilmuwan dan sejarawan Indonesia meyakini bahwa sejarah panjang Indonesia tidak lepas dari nama M. Natsir. M.Natsir (1908-1993) yang merupakan salah satu pejuang di samping pahlawan lainnya sebagai “the founding fathers". Lebih dari itu, M. Natsir merupakan pahlawan NKRI, ketika negara yang baru dilahirkan itu tercabik-cabik kedalam negara-negara boneka ciptaan Belanda di samping Negara Republik Indonesia M. Natsir berperan sebagai sosok yang secara genuine menyodorkan sebuah konsep integral dan disepakati oleh semua.

Sebagaimana dicatat dalam sejarah, KMB (Konferensi Meja Bundar) di Den Haag menelorkan Republik Indonesia Serikat (RIS). RIS ini tidak lain adalah boneka dari negara-negara bikinan Belanda. M. Natsir, sebagai pemimpin partai Islam Masjumi dan anggota BP KNIP 
sebelumnya, yang mengajukan "mosi integral" agar RIS dilebur dan menjadi NKRI. Semua negara-negara itu, baik yang bikinan Belanda maupun yang RI sendiri, berintegrasi ke dalam NKRI -Negara Kesatuan Republik Indonesia. Dan Mohammad Natsir adalah Perdana Menteri Pertamanya.

Lahirnya mosi integral tidak lepas dari kondisi Indonesia yang sempat bergejolak. Pada 27 Desember 1949 lahir sebuah Republik Indonesia (RIS) Serikat menggantikan Negara Kesatuan Republik Indonesia (NKRI). Terbentuknya RIS adalah pukulan bagi Indonesia yang umur kemerdekaanya barulah seumur jagung. Negara bentukan RIS tergabung dalam Bijeenkomst voor Federaal Overleg. Tokoh kolonial pembentukan negara bagian ini adalah Letnan Gubernur Jenderal Hindia Belanda Hubertus Johannes van Mook.

Sebagaimana dikutip islamindonesia.co.id aecara resmi, Bijeenkomst telah terbentuk sejak pelaksanaan Perjanjian Linggarjati 1946. Dengan kelicikan dan pencaplokan kembali Indonesia, van Mook memecah Indonesia lewat pembentukan negara bagian. Lewat RIS, van Mook memecah NKRI dengan membentuk negara bagian yang di dalamnya ada Republik Indonesia, Negara Indonesia Timur, Negara Borneo, menjadi 16 negara bagian.

Kelicikan van Mook memecah belah Indonesia diterima banyak daerah sebab tiap daerah akan memiliki kewenangan sendiri. $\mathrm{Mr}$ Mohammad Roem menyebut, "Memang sangat menarik untuk membentuk negara bagian, lebih-lebih untuk menjadi kepala negaranya. Orang memperoleh segala fasilitas keuangan dan teknis dari pemerintah Hindia Belanda."

Usaha Belanda memecah Indonesia dengan RIS membuat tokoh republikan menyebutnya sebagai negara boneka "Negara boneka bikinan van Mook".

Natsir bermanuver melihat situasi perpecahan. Diskusi ekstrem antar ideologi terjadi. Kesepahaman diambil dengan rekannya di parlemen, yaitu Kasimo dari Partai Katolik dan A. M. Tambunan dari Partai Kristen Indonesia. Diskusi alot pun terjadi dengan kekuatan politik ekstrem lainnya pada saat itu: Partai Komunis Indonesia di sisi kiri dan Bijeenkomst voor Federaal Overleg di sisi kanan.

Sebelum akhirnya pada 3 April 1950 Natsir pun menyampaikan sebuah pidato ajakan untuk sebuah persatuan, M. Natsir sebelumnya melakukan loby-loby politik selama 2,5 bulan. Waktu itu dipergunakan untuk meyakinkan para anggota partelem dan para petinggi Negara untuk meyakini akan pentingnya persatuan dan bahayanya RIS. Pidato 
bersejarah di depan parlemen Republik Indonesia yang dikemudian hari dikenal sebagai "Mosi Integral". Isi dari pidato tersebut ditutup dengan sebuah pernyataan kuat yang intinya: "Dewan Perwakilan Rakyat Sementara republik Indonesia Serikat dalam rapatnya tanggal 3 April 1950 menimbang sangat perlunya penyelesaian yang integral dan pragmatis terhadap akibat-akibat perkembangan politik yang sangat cepat jalannya pada waktu akhir-akhir ini”.

Isi Mosi Integral adalah undangan untuk pemerintah agar berinisiatif mencari penyelesaian terhadap gejolak perpecahan yang ada. Ajakan Natsir pada pidatonya bukanlah sekadar ajakan kepada negara bagian untuk kembali ke negara kesatuan. Natsir menegaskan bahwa mosinya tidak berhubungan dengan kontroversi negara kesatuan dan negara federal dengan menyatakan "menjauhkan diri dari pembicaraan soal unitarisme dan federalisme. Perjuangan Natsir bukan sekadar "negara kesatuan", tetapi "persatuan bangsa" sehingga dia menyebut sebagai integral dalam pidatonya.

Karena sebelumnya sudah melakukan loby, maka mosi integral dari Natsir disambut dengan baik oleh parlemen dan pemerintah. Mohammad Hatta, perdana menteri sekaligus wakil presiden pada saat itu pun menyambutnya dengan tangan terbuka. Hatta mengatakan, "Mosi Integral Natsir kami jadikan pedoma menyelesaikan persoalan-persoalan yang sedang dihadapi."

Pada akhirnya, 19 mei 1950 diadakan perundingan pemerintah Republik Indonesia Serikat yang mewakili Indonesia Timur dan Sumatera Timur dengan Republik Indonesia. Perundingan itu menghasilkan piagam yang ditandatangai Perdana Menteri republik Indonesia Serikat Mohammad hatta dan Perdana Menteri Republik Indonesia Dr. Halim.

Piagam tersebur berisi kesepakatan NKRI dan RIS membentuk sebuah negara kesatuan. Presiden Soekarno membacakan Piagam pembentukan NKRI dalam sidang bersama parlemen dan senat RIS. Tepat pada hari proklamasi Indonesia, Presiden Soekarno mengumumkan lahirnya negara Kesatuan Republik Indonesia.

Inilah yang menurut banyak pihak disebuat bahwa Indonesia lahir kembali dengan nama Negara Kesatuan Republik Indonesia. Dan Muhammad Natsir adalah tokoh utama dari terbentuknya NKRI.

Menurut Mochtar Naim (2008: 203), konsep NKRI yang ada dalam kepala Natsir waktu itu adalah dengan memberikan hak dan peluang yang sama untuk semua daerah yang orientasinya bukanlah sentralistik tetapi desentralistik. Natsir ingin melihat bahwa NKRI itu 
tidak ada daerah yang dianak emaskan atau dianak tirikan, semua diperlakukan sama dalam satu kesatuan kenegaraan yang utuh.

Ini dibuktikan oleh sikap dan tindakan Natsir sendiri, ketika pemberontakan PRRI pecah, Natsir bersama Syafuddin Prawiranegara dan Burhanuddi Harahap memilih untuk bergabung dengan Dewan Banteng, dll membentuk PRRI, karena Natsir melihat dalam pertarungan antara pusat dan daerah itu, daerahlah yang menafsirkan NKRI itu secara benar dan konsekuen, sementara Soekarno menginginkan agar kekuasaan negara terpusat ketangannya selaku presiden dan kepala negara dan menghidupkan kembali sistem kekuasaan absolut seperti di zaman Majapahit dan Mataram dahulu.

Daerah pada saat itu tidak hanya diperlakukan sebagai obyek tetapi juga sebagai kuda beban pelajang bukit untuk kebesaran dan kemegahan pusat. Walau tidak lagi seperti zaman kerajaan, tetapi etatisme, feodalisme dan paternalisme dihidupkan kembali yang mendasari hubungan biroktarik atas-bawah dan hubungan antara penguasa dan rakyat. Rakyat yang dalam konsep NKRI adalah pemegang kedaulatan sekarang diturunkan kembali sebagai abdi dan akwula negara yang mengabdi pada kekuasaan absolut dari pengasa tertinggi negara. Dan impian ini segera di realisasikan oleh Soekarno mengambil alih seluruh kekuasaan dan menjamin dirinya sebagai presiden seumur hidup dan menyandang gelar "bapak bangsa" dan 'pemimpin besar revolusi'. Dan ini sekaligus menghapus keputusan apapun yang telah dihasilkan oleh Dewan Konstituante di Bandung dalam rangka mendudukkan dasardasar negara dalam konstitusi baru pengganti UUD 1945. UUD 1945 yang disiapkan secara tergesa-gesa yang tadinya hanya bersifat sementara sekarang dikukuhkan menjadi permanen melalui dekrit presiden itu.

Naim (2008: 204) juga menjelaskan bahwa konsep NKRI menurut Natsir dan PRRI tidak sama dengan konsep NKRI yang dipaksakan oleh pusat di bawah kendali presiden Soekarno - kemudian Soeharto - yang kental orientasi sentralistime atatik dan Jawa - sentriknya itu. Jika kita pilah kembali apa yang menjadi tuntutan PRRI yang sekaligus mewakili tuntutan daerah seluruh Indonesia itu, identik dengan yang diperjuangkan oleh kekuatan revormasi sekarang ini. NKRI Natsir dan PRRI menginginkan pembahagian rezeki antar daerah dan antara pusat dan daerah yang adil dan merata, pun juga begitu dengan tuntutan reformasi. Dst, dst. Bahwa dengan membagi kue pembangunan itu secara adil dan merata ke daerah-daerah maka semua daerah akan bangun, dan tak ada yang merasa ditinggalkan. Dalam konteks keadilan dan pemerataan itu maka yang kuat akan membantu yang lemah, yang 
kaya akan membantu yang miskin, dan yang sudah lebih maju akan memberi peluang lebih banyak kepada orang yang tertinggal. Indonesia yang luas ini sesungguhnya tak lain dari jumlah keseluruhan (the sum total) dari daerah-daerah itu yang dilihat dan diperlakukan sebagai satu kesatuan yang integral.

Esensinya, oleh karena itu, antara NKRI konsep Natsir dengan cita perjuangan PRRI dan keinginan daerah-daerah lainnya adalah satu, dan ini bertentangan dengan konsep NKRI yang dihembuskan atau bahkan dipaksakan oleh para pentolan nasionalis ultra yang orientasinya adalah pada kegemahan dan kebesaran pusat kekuasaan dengan model kerajaan di zaman Majapahit dan Mataram itu. Lihatlah, seperti yang ada sekarang ini, betapa menyoloknya perbedaan antara Jakarta dan kota-kota besar lainnya di Jawa, dengan keadaan daerah-daerah diluar jawa yang banyak diantaranya masih seperti sediakala dan belum tersentuh oleh tangantangan pembangunan. Bagian besar dari penghasialn negara berasal dari daerah-daerah di luar Jawa semntara bagian besar dari pemakaiannya diletakkan di Jawa. Jawa telah menjadi pusat industri, perdagangan dan pelayanan ekonomi lain-lainnya, dengan gedung-gedung pencakar langit, jalan-jalan tol yang berseliweran dan bertingkat-tingkat, dan mal-mal, supermarket dan tempat-tempat hiburang dan olahraga sudah seperti luar negeri di negara-negara maju lainnya. Yang terjadi, bukan yang kuat membantu yang lemah, tetapi yang lemah diperas lagi untuk memperkuat yang telah kuat. Dan ini dipicu lagi oleh kecenderungan "resentralisasi" belakangan ini melalui jalur-jalur sektoral dan depertemen-departemen yang tadinya wewenangnya sudah diserahkan kepada daerah-daerah, tetapi ditarik kembali dengan berbagai peraturan dan ketentuan yang diatur langsung oleh pusat melalui departemen-depertemen itu.

Dari segi ini kita melihat betapa jauhnya jangkauan visi ke depan dari Natsir, tetapi diartikan salah oleh kelompok yeng berfikiran etatik dan terpusat itu. Akibatnya, maka beginilah jadinya. Karena konsep NKRI Natsir perlu diterjemahkan ulang kembali sesuai dengan konsep aslinya semula. Bahwa Indonesia adalah satu dan satu kesatuan, tetapi dalam kesatuan itu semua mendapatkan hak dan peluang yang sama, terlepas dari perbedaan corak budaya, agama, dan latar belakang etnik dan sosio-kultural lain-lainnya.

Konsep "tasamub" atau toleransi dari Natsir adalah bahagian yang tak terpisahkan dari konsep integral itu. Walau Natsir dna kawan-kawan di Konstituante Bandung memperjuangkan ideologi kenegaraan yang berdasarkan Islam, yang dimaksudkan adalah Islam yang tasamuh dan toleran itu, sesuai dengan ajaran Islam itu sendiri. 
Dengan prinsip hidup yang dimulai dengan ikhlas, M. Natsir muncul sebagai sosok panutan yang bukan hanya negarawan tetapi ulama besar yang karismatik. Publik banyak mengenal beliau dengan sifat jujur, amanah, berani karena benar, takut karena salah, dan istiqomah dalam sikap dan pendirian. Selain itu, M. Natsir juga zuhud, qana'ah, sehingga lebih memilih untuk hidup dibalik jeruji besi dan didekam untuk masa yang tak diketahui berapa lamanya, daripada meluncurkan diri secara politis dan menggadaikan iman dan keyakinan seperti yang dilakukan oleh banyak orang dan banyak pemimpin di Republik ini.

Konsep "integral" dan "toleransi" yang diartikan secara murni kaffah yang intinya adalah ajaran Islam itu sendiri ternyata adalah juga pakaian beliau yang beliau bawa sampai mati.

\section{Latar Kelahiran Mosi Integral}

Dalam komunikasi, pesan yang disampaikan merupakan respon dari stimulus yang didapatkan. Dari stimulus kemudian dipersepsi oleh penerimanya, setelah itu maka lahirlah respon. Respon itu bisa dilakukan secara spontan atau juga tidak. Seperti halnya feed back, ada yang langsung ada juga yang tertunda (delayed feed back).

Oleh karena itu, setiap pesan yang disampaikan pasti memiliki awal mulanya mengapa hal itu bisa keluar. Pesan dalam bahasa lain memiliki alur ceritera atas stimulus sebelum respon itu muncul. Pesan tidak tiba-tiba datang kecuali sebelumnya diawali oleh sebuah situasi dan kondisi yang merangsang pesan itu lahir.

Begitupun dengan kasus mosi integral. Jika mosi integral diposisikan sebagai pesan dalam komunikasi politik, maka mosi integral M. Natsir tersebut pasti memiliki latar belakang mengapa mosi integral sebagai pesan itu lahir. Di sinilah kajian pesan akan sangat terkait dengan stimulus yang terjadi pada saat mosi integral itu belum lahir. Karenanya, M. Natsir pasti sebelum itu melihat, mendengar, atau melewati sebuah fase sejarah tertentu hingga akhirnya dirinya berfikir keras dan mendorong untuk melakukan lawatan ke berbagai daerah untuk mencari tahu apa yang terjadi dan menjadi aspirasi masyarakat.

Mosi Integral tidak lahir dengan sendirinya. Pada saat itu situasi politik negara Indonesia dalam kondisi tidak menentu. Indonesia sedang tidak jelas arahnya, bahkan terancam terjadi perpecahan, karena munculnya negara-negara kecil di berbagai daerah di Indonesia. Hal ini disebabkan hasil Konverensi Meja Bundar di Den Haag yang melahirkan Republik Indonesia Serikat. 
Republik Indonesia Serikat dalam kacamata M. Natsir merupakan upaya Belanda untuk memecah belah Negara Indonesia. Dengan membentuk negara-negara bagian, artinya negara kesatuan ini dibagi-bagi menjadi terdiri dari negara-negara kecil.

Van Mook yang menjadi penggagas RIS menjadi orang yang paling bertanggungjawab atas terjadinya gejolak di berbagai daerah di Indonesia. Hal ini disebabkan tidak siapnya rakyat Indonesia untuk menjadi negara bagian. Ketidak siapan ini juga yang kemudian menimbulkan kebingungan di kalangan masyarakat secara luas. Maka apa yang terjadi kemudian adalah kerusuhan dan konflik sosial terjadi di mana-mana. Setiap daerah mengalami disorientasi, tidak jelas arah maka yang terjadi adalah konflik horizontal. Gejolak yang terjadi itu tentu saja karena Indonesia yang terdiri dari pulau-pulau itu, berdasarkan hasil KMB dibagi menjadi 16 negara bagian, dan tentu saja rakyat Indonesia marah dan menolak.

Apa yang terjadi pada negara Indonesia itu menimbulkan keprihatinan bagi M. Natsir. Pada saat itu M. Natsir menjadi anggota parlemen sekaligus ketua Fraksi Masyumi. Kondisi negara yang bergejolak menggerakkan politisi religius ini untuk kemudian dengan sendirinya mencari tahu terhadap apa yang terjadi di berbagai pelosok tanah air. M. Natsir kemudian keliling ke berbagai daerah untuk menangkap aspirasi dari masyarakat tentang apa yang diinginkan oleh masyarakat.

Kepekaan seorang politisi memang sangat dituntut di sini - bukan hanya kecerdasan semata. Dengan kepekaan itu kemudian M. Natsir menemukan sebuah kesimpulan penting dari aspirasi dari masyarakat atau daerah-daerah yang ada di Indonesia. Ternyata masyarakat Indonesia atau daerah-daerah itu sesungguhnya tidak setuju dengan RIS dan mereka menginginkan tetap berada pada satu negara yang utuk yaitu Indonesia.

Maka ketemu akhirnya, apa yang menjadi stimulus sebelum mosi integral itu lahir, berupa situasi bangsa Indonesia yang terancam terpecah belah akibat ulah Van Mook yang melahrkan RIS lewat momentum KMB di Den Haag Belanda. Dari KMB ini maka lahirlah negara-negara boneka, yang jika diselami lebih dalam dari hati nurani rakyatnya, sesungguhnya mereka tidak menerima hal itu terjadi. Maka mosi integral merupakan respon M. Natsir atas kondisi tersebut.

Dari sini, kemudian M. Natsir membuktikan kepiawaiannya dalam berpolitik. Apa yang dilakukannya yaitu melobi para politisi yang ada di gedung parlemen dari berbagai fraksi. M. Natsir meyakinkan kepada 
semuanya kalau RIS bukanlah pilihan yang tepat dan justru kita harus kembali kepada negara kesatuan. Setelah menggerilya anggota parlemen, M. Natsir pun kemudian melakukan lobi kepada pemerintah. Selain menginformasikan apa yang terjadi di berbagai belahan negara Indonesia, juga menyampaikan aspirasinya.

Dari sinilah kemudian M. Natsir memikirkan sesuatu yang lebih solutif bagi bangsa yang besar ini. Pada saat itu M. Natsir kemudian menyusun sebuah konsep sebuah mosi yang kemudian dikenal sebagai mosi integral M. Natsir hingga saat ini. Konsep mosi integral disusun oleh M. Natsir setelah menangkap aspirasi masyarakat yang menginginkan bersatunya negara-negara bagian tersebut ke dalam Republik Indonesia.

Seteleh melalui perenungan dan pemikiran yang jernih, mosi integral disusun oleh M. Natsir untuk kemudian dibacakan di sidang parlemen. Setelah sebelumnya dilakukan lobi-lobi politik, maka pada 3 April 1950, M. Natsir membacakan konsepnya itu dalam sidang gabungan RIS-RI, yang kemudian dikenal dengan mosi integral.

Apa yang menjadi gagasan besar dan kemudian dapat menyelamatkan bangsa ini tidak lain merupakan gagasan murni dari $\mathrm{M}$. Natsir sendiri. Tanpa mengadopsi dan didorong oleh pihak lain, $\mathrm{M}$. Natsir menggali konsep mosi integral dari aspirasi masyarakat yang tersebar di berbagai daerah di Indonesia, sehingga bisa dikatakan bahwa mosi integral merupakan konsep yang digali dari rahim dan jatidiri bangsa yang menginginkan bersatunya Indonesia dalam satu wadah tidak terbagi-bagi.

\section{Mosi Integral Sebagai Pesan Politik}

Sebagai pesan dalam komunikasi politik, mosi integral memiliki nilai penting bagi M. Natsir. Terlebih jika mosi integral ini sebelumnya telah melakukan proses riset yang mendalam terhadap segenap rakyat yang tersebar di daerah-daerah yang pernah diajak dialog oleh M. Natsir. Maka mosi integral menjadi vital dalam konteks politik dengan harapan dapat memberikan inspirasi bahkan mengubah kebijakan pemerintah. Pesan politik ini sangat pundamental sebab mengubah bentuk Negara yang dibuat oleh orang banyak melalui sebuah pertemuan besar di Belanda, sementara harus dirubah oleh seorang M. Natsir seorang diri sebagai pemilik tunggal gagasan mosi integral.

Mosi integral sebagaimana dijelaskan di atas merupakan gagasan murni dari M. Natsir. Apa yang menjadi pemikirannya dapat memberikan 
kontribusi besar bagi terjalinnya persatuan bangsa Indonesia. Ketika bangsa ini terancam terpecah-pesan karena hasil KMB, maka M. Natsir dengan tepat mengantisipasi lewat kemampuan berfikirnya yang jernih.

Pada saat itu, menurut M. Natsir, masalah pokok yang harus dipecahkan adalah bagaimana membentuk Negara Kesatuan Republik Indonesia (NKRI). NKRI pada saat ini merupakan jawaban dari persoalan dari kondisi politik yang ada. NKRI menginginkan terjadinya penggabungan negara-negara bahagian ke RI Yogyakarta atau langsung semua negara-negara bahagian ke NKRI.

Dalam prakteknya, konsep mosi integral adalah menyatukan seluruh daerah dilakukan secara damai. Jika ada konflik dalam penyatuan Negara Indonesia ini, maka yang dirugikan adalah masyarakat. Maka, konsep mosi integral mencerminkan sebuah aspirasi bersama sehingga dapat diterima semua kalangan.

Ketika mosi integral Natsir diterima parlemen, maka pada tanggal 17 Agustus 1950 negara kesatuan pun kembali berdiri, meskipun Irian Barat masih merupakan wilayah sengketa. Walaupun banyak yang melupakannya, namun tidak bisa dihapus dalam sejarah bangsa Indonesiai bahwa mosi integral itu menjadi inspirasi penting untuk berdirinya Negara Indonesia yang kedua sehingga dipersatukan oleh tekad yang kuat. Seluruh isi 'Mosi Integral M. Natsir' tertuang dalam sebuah naskah autentik DPR Sementara RIS.

Pada tanggal 2 April Mohammad Natsir menyampaikan pidato 'mosi integral' yang bersejarah tersebut, dengan beberapa butir latar pemikiran yang penting (1) Semua negara-negara bahagian mendirikan NKRI melalui prosedur parlementer, (2) Tidak ada satu negara bahagian menelan negara bahagian lainnya dan (3) Masing-masing negara bahagian merupakan bahagian integral dari NKRI yang akan dibentuk.

Kewibawaan sebuah pesan tentu saja tidak bisa lepas dari pembuat pesannya itu sendiri. M. Natsir merupakan sosok penting dan sangat berpengaruh pada zamannya, sehingga pesan yang disampaikannya dapat diterima oleh semua pihak. Karenanya, dalam komunikasi, figure adalah bagian tidak terpisahkan dari pesan itu sendiri. Sehingga dalam konteks politik, komunikator politik menjadi sangat vital dan menentukan sampai atau tidaknya sebuah pesan politik. Kebetulan, mosi integral lahir dari sosok M. Natsir, dan dia sendiri yang menjadi tokoh penyampainya mulai dari pola komunikasi interpersonal melalui loby-loby politik, hingga komunikasi berbentuk massa yaitu lewat pidato terbuka di gedung parlemen. 


\section{Proses Sosialisasi Mosi Integral}

Mosi integral, sebagai pesan komunikasi politik M. Natsir setidaknya mencakup aktivitas utama dalam proses sosialisasi sebagaimana dijelaskan David Krech. Ada tiga Teori inti yang berkenaan dengan proses sosialisasi pesan-pesan, yang dalam kajian ini dinyatakan sebagai proses sosialisasi pesan-pesan politik. Pertama, untuk menjelaskan proses tersebut, Krech menyebutkan bahwa "communication - the interchange of meaning among people - occurs mainly through language and is possible to the degree to wich individuals have common cognitions, wants, and attitudes." Teori ini paling tidak menyebutkan dua hal penting yang terlibat dalam proses komunikasi: kesamaan individual dalam aspek kognisi (cognitions), kehendak (wants) dan sikap (attitudes).

Di sini M. Natsir melakukan sosialisasi mosi integral kepada seluruh pejabat pemerintah, termasuk anggota parlemen selama berbulan-bulan. M. Natsr menyampaikan pesan kepada orang lain untuk membangun kesamaan makna yaitu pentingnya menyatukan kembali bangsa Indonesia dalam bentuk Negara kesatuan. Maka selama 2,5 bulan yang diakhir dengan pidato di gedung parlemen itu, M. Natsir memberikan pemahaman agar secara kognisi seluruh pihak dapat memiliki wawasan yang sama, memiliki kehendak yang sama, sehingga pada saatnya, seluruh elemen bangsa menganggap bahwa mosi integral sebagai kebutuhan bersama. Sehingga sikap dari pemerintah dan anggota parlemen memiliki kesamaan.

Dengan bahasa yang santun dan tidak meledak-ledak, bagi Krech, M. Natsir sudah menyampaikan symbol-simbol komunikasi yang khas. Setiap kata-kata yang disampaikannya merupakan pesan itu sendiri untuk menunjukkan siap sebenarnya M. natsir.

Dalam konteks sosialisasi politik, secara spesifik teori ini lebih jauh menjelaskan bahwa proses sosialisasi politik (political socialization) itu meliputi aspek-aspek bagaimana seseorang belajar politik, kelembagaan politik, dan bagaimana seseorang pada akhirnya berperilaku politik tertentu. Maka di sini kita akan melihat bagaimana M. Natsir menjadikan mosi integral tidak hanya sebaga pesan yang dipaksanakan dan didoktrinkan, tetapi disampaikan melalui sebuah proses pendidikan politik. Setiap anggota parlemen diajak dialog, termasuk para petinggi negaranya. Mosi integral sebagai materi pendidikan politik untuk membangun pemahaman bersama yang ujung-ujungnya adalah perilaku politik yang pro terhadap persatuan bangsa, dengan membubarkan Negara-negara boneka bentukan Belanda. 
Karena pentingnya sosialisasi, maka dalam komunikasi politik interaksi turut menentukan mempengaruhi hubungan antara masyarakat dengan kekuasaan. Sedangkan secara teknis, sosialisasi politik merupakan proses belajar, penerimaan, dan improvisasi kebiasaan-kebiasaan dan aturan-aturan, struktur-struktur, serta faktor-faktor lingkungan yang membentuk kehidupan politik. Dengan demikian implisit, teori ini juga menjelaskan bahwa sosialisasi politik senantiasa melibatkan aspek-aspek pendidikan politik, kesadaran politik dan partisipasi politik itu sendiri. Itu pula yang dilakukan M. Natsir dengan mosi integral.

Kedua, teori yang berkenaan dengan proses perumusan pesan-pesan komunikasi. Menurut Krech, pesan-pesan komunikasi pada umumnya dirumuskan dengan mempertimbangkan konteks verbal dan konteks nonverbal. Konteks ini dipertimbangkan karena pada tahap tertentu keduanya dapat mempengaruhi proses pemaknaan terhadap simbolsimbol yang digunakannya. Secara verbal, kata-kata pada dasarnya tidak berdiri sendiri.

Di sini, M. Natsir merumuskan mosi integral dari sebuah proses penjang. Pesan-pesan sebelumnya dirumuskan dari serpihak pendapat dan aspirasi masyarakat baik yang disampaikan secara verbal maupun non verbal. Kehendak rakyat di daerah-daerah yang terusik dan terus bergejolak menunjukkan bahwa RIS bukanlah pilihan tepat bagi bangsa Indonesia.

Ketiga, teori yang berkenaan dengan konteks kelompok tempat sesuatu interaksi dapat berlangsung. Teori ini diperlukan terutama untuk memahami, menjelaskan dan meramalkan interaksi kelompok ataupun hubungan antar individu dalam komunitas tertentu. Dalam konteks ini, M. Natsir menjadikan parlemen sebagai kelompok yang paling menentukan perubahan RIS menjadi NKRI. Maka proses sosialisasi dalam konteks kelompok ini dimaksimalkan oleh M. Natsir agar semua orang dapat terbangun pemahamannya.

Teori ini juga menyatakan bahwa efektivitas komunikasi politik dalam sebuah kelompok juga sangat ditentukan oleh gaya seorang pemimpin yang menyampaikan pesan, motivasi dan hubungan di antara anggota kelompok itu. Sosok M. Natsir di sini begitu disorot, sebab bukan hanya anggoat parlemen biasa, tetapi M. Natsir sebagai ketua Fraksi, Ketua Umum Partai Masyumi, juga sebagai ulama besar yang cukup dikenal pada saat itu. Sosok tokoh ini dalam proses sosialisasi menjadi penting dan rutut mempengaruhi pesan yang disampaikannya.

Oleh karena itu, pendapat MC Nair dalam hal ini menjadi relevant dengan mengatakan bahwa tujuan seseorang melakukan komunikasi 
politik adalah sebagai bagian dari proses pembelajaran politik, yang terjadi akibat adanya proses pertukaran informasi. Aktor politik dapat belajar memahami konstituen, masyarakat dan pemberitaan media, demikian juga sebaliknya.

Komunikasi politik juga bertujuan untuk menumbuhkan partisipasi dalam politik (political participation). Melalui proses pembelajaran politik, orang mengembangkan kepercayaan, nilai dan pengharapan yang pada gilirannya mendorong untuk berpartisipasi dalam politik, wujudnya bisa berbentuk memberikan suara pada saat pencoblosan atau dalam kasus mosi integral adalah ketika seluruh anggota parlemen menyetuji apa yang menjadi pesan M. Natsir yaitu mosi integral.

Secara umum memang, mosi integral lebih dikenal ketika dipidatokan oleh M. Natsir di depan sidang gabungan RIS-RI pada 3 April 1950. Namun, sesungguhnya sebelum pidato itu dilakukan, M. Natsir terlebih dahulu melakukan lobi politik kepada seluruh fraksi di parlemen. Dengan posisi sebagai ketua Fraksi Masyumi, maka kondisi itu lebih memudahkan M. Natsir melakukan lobi politik.

Selaku Ketua Fraksi Masyumi, Natsir mencermati keadaan yang berkembang. Natsir pun menemui para Ketua Fraksi untuk mengetahui fikiran apa yang sedang berkembang di parlemen. Natsir berdiskusi dengan para pemimpin fraksi paling kiri melalui Ir. Sakirman dari Partai Komunis Indonesia (PKI). Natsir juga berdiskusi dengan pemimpin fraksi yang sangat kanan, Sahetapy Engel dari Bïjeenkomst voor Federaal Overleg (BFO).

Dari pertukaran fikiran itu, Natsir menyimpulkan bahwa negaranegara bagian itu mau membubarkan diri untuk bersatu dengan Republik Indonesia di Yogya, asal jangan disuruh bubar. Sepanjang dua setengah bulan, Natsir melakukan lobby yang diakuinya tidak mudah, terlebih-lebih dengan negara-negara bagian di luar Jawa seperti negara bagian di Sumatera dan Madura. Setelah semuanya dirasa mantap, Natsir mengajukan Mosi Integral yang menurut pengakuannya, dibuat "kaburkabur...." Mosi Integral dibikin kabur, karena kita tengah menghadapi Belanda. "Jangan sampai nanti Belanda bikin kacau lagi. Belanda tidak boleh tabu, mau ke mana perginya rencana itu," kata Natsir.

Karena sosialisasi yang baik terhadap gagasan besarnya itu, maka mosi integral Natsir diterima baik oleh pemerintah. Perdana Menteri RIS, Mohammad Hatta, mengumumkan bahwa pemerintah akan menggunakan Mosi Integral Natsir sebagai pedoman dalam memecahkan persoalan-persoalan yang dihadapi. Dengan pendekatannya yang luwes, Natsir berhasil memulihkan negara federal RIS ke NKRI tanpa satu 
orang pun yang dipermalukan, juga tanpa setetes darah pun yang tumpah.

Yang paling penting dalam upaya meyakinkan orang lain adalah keyakinan diri dulu. Natsir merasa yakin bahwa untuk kepentingan bangsa, ide brilian tersebut dapat diterima oleh fraksi. Walaupun ada juga diantara negara bagian yang merasa harga dirinya terganggu bila melebur yaitu negara bagian RI Yogyakarta. Lobi terhadap mereka dilakukan dengan "ancaman".

\section{Penutup}

Dari hasil penelitian di atas, peneliti dapat menyimpulkan bahwa mosi integral yang kemudian menjadi pesan komunikasi politik, menjadi salah satu pemikiran M. Natsir yang sangat penting. Oleh karena itu penelitian ini setidaknya dapat menyimpulkan tiga hal penting:

Pertama, pasca sidang KMB di Belanda, kondisi Negara Indonesia semakin tidak menentu karena disepakatinya Republik Indonesia Serikat (RIS) yang realisasinya adalah memecah-mecah Negara Indonesia menjadi Negara bagian. Kondisi ini menjadi latar belakang M. Natsir untuk merumuskan sebuah mosi yang kemudian dikenal dengan mosi integral.

Kedua, mosi integral menjadi pesan politik yang sangat penting karena menjadi tonggak kelahiran kembali Negara Indonesia. Lahir murni dari pemikiran M. Natsir, setelah melakukan penelitian secara mendalam kepada masyarakat yang ada di daerah-daerah di Indonesia. Ketika masyarakat menginginkan kembalinya Negara serikat menjadi kesatuan, maka M. Natsir merumuskan sebuah konsep mosi integral. Mosi ini berisi tentang pentingnya menyatukan daerah-daerah dan masyarakatnya dalam sebuah persatuan, tanpa terpecah-pecah.

Ketiga, sebelum melakukan pidatonya di depan parlemen, M. Natsir melakukan sosialisasi kepada beberapa pihak. Sebagai komunikator politik, M. Natsir selain mensosialisasikan gagasannya kepada para anggota parlemen yang ada di berbagai fraksi. Selain itu, M. Natsir juga mensosialisasikan mosi integral kepada kalangan eksekutif. Dengan melakukan sosialisasi atau lobi ke berbagai kalangan termasuk para pengambil kebijakan, M. Natsir tidak terlalu kesulitan untuk mendapatkan persetujuan penuh terhadap konsep yang ditawarkannya itu. 


\section{Daftar Pustaka}

Abel Tasman. 2007. Natsir dan Warisan Yang Terabaikan. padangmedia.com, Website: http://www.rantaunet.org

Ahmad Suhelmi. 1999. Soekarno versus Natsir. Darul Falah, Jakarta.

Ajip Rosidi. 1990. Mohammad Natsir Sebuah Biografi. PT. Giri Mukti, Jakarta. Hendra Gumilang. 2000. M. Natsir dan Darul Islam (studi Kasus Aceh dan Sulawesi Selatan Tabun 1953-1958). Media Da'wah, Jakarta.

Akh. Muzakki. 2004. Mengupas Pemikiran Agama \& Politik Sang Pahlawan Reformasi, Penerbit Lentera, Jakarta

Alex Sobur. 2001. Analisis Teks Media, Suatu Pengantar Untuk Analisis Wacana, Analisis Semiotik, dan Analisis Framing. Remaja Rosdakarya. Bandung.

Amien Rais. 2004. Hubungan Antara Politik dan Dakwah: Berguru kepada M. Natsir. Mujahid Press, Bandung.

Amrullah Ahmad. 2008. Mohammad Natsir Muslim Teolog-IntelektualIdio-Praxix dalam Dakwah Islam, dalam 100 Tabun Mohammad Natsir: Berdamai dengan Sejarah, Republika, Jakarta.

Ardial. 2010. Komunikasi Politik. Indeks, Jakarta.

Asep Saeful Muhtadi, Komunikasi Politik Indonesia, Rosda, Bandung, 2009

Burhanuddin Agus. 2008. Mohammad Natsir Demokrat Tulen, dalam 100 Tahun Mohammad Natsir: Berdamai dengan Sejarah, Republika, Jakarta.

Dan Nimmo. 1989. Komunikasi Politik: Komunikator, Pesan dan Media . Rosda, Bandung. . 2001. Komunikasi Politik: Khalayak dan Efek. Rosda, Bandung.

David Krech. 1962. Individual in Society. McGraw Hill, California.

Dedi Mulyana. 2003. Ilmu Komunikasi Suatu Pengantar. Rosda, Bandung.

Deddy Mulyana. 2006. “MetodologiPenelitianKualitatif”. PT Remaja Rosdakarya Bandung

Deliar Noer. 2000. Partai Islam Dipentas Nasional, Kisah dan Analisis Perkembangan Politik Indonesia 1945-1965. Mizan Bandung

Deliar Noor. 1980. Gerakan Modern Islam di Indonesia (1900-1942). LP3ES. Jakarta 1985. Partai Islam di Pentas Nasional. Pustaka Utama Grafiti. Jakarta.

Eef Saefulloh Fatah. Mohammad Natsir Tentang Demokrasi, Republika Jumat, 20 Januari 1995, H. 9. 
Gabriel. Almond. 1960. Budaya politik;tingkah laku politik dan demokrasi di lima Negara. Bina Aksara, Jakarta.

Gusti Adnan. 2008. PRRI: Pemberontaan atau Pergolakan Daerah, dalam 100 Tahun Mohammad Natsir: Berdamai dengan Sejarah, Republika, Jakarta.

Hafied, Cangara. 2009. Komunikasi Politik. Rajawali Press, Jakarta.

Hendra Gunawan. 2000. M. Natsir dan Darul Islam. Media Dakwah, Jakarta.

Herman Nicholas Vantje Sumual. 2008. M. Natsir dan PRRI, dalam 100 Tabun Mohammad Natsir: Berdamai dengan Sejarah, Republika, Jakarta.

Holid O. Santoso. 2003. Dasar Negara Islam Indonesia: Pemikiran dan Aksi Politik M. Natsir. LP2EPI, Bandung. . 2007. Pemikiran dan Gerakan Tokoh-tokoh Islam. Sega Arsyi. Bandung

Jalaludin Rahmat. 2001. Metode Penelitian Komunikasi,: Remaja Rosda Karya Bandung.

K. Bertens. 2011. Etika. Gramedia, Jakarta.

Kholid O. Santoso. 2009. Mendari Demokrasi Gagasan dan Pemikiran.Sega Arsyi, Bandung.

Lukmah Hakiem. 2008. M. Natsir di Panggung Sejarah Republik. Republika, Jakarta.

.(Penyunting). 1993. Pemimpin Pulang: Rekaman Peristiwa Wafatnya M. Natsir, Yayasan Piranti Ilmu, Jakarta.

M. Amien Rais. 2004. Hubungan Antara Politik dan Dakwah: Berguru Kepada M. Natsir. Mujahid, Bandung.

Mochtar Naim. 2008. Mohammad Natsir Dengan Konsep Integral dan Toleransinya, dala 100 Tahun Mohammad Natsir: Berdamai dengan Sejarah, Republika, Jakarta.

Mohammad Natsir. 2000. Fiqhud Da'wah, Media Da'wah, Jakarta, 1954. Capita Selecta. W. Van Hoeve, Bandung: 1954

, Capita Selecta 2. Abadi Jakarta, 2008

2004. Islam Sebagai Dasar Negara: Pidato Pada Sidang

Pleno Konstituante tanggal 12 Nopember 1957. Sega Arsyi, Bandung . 1984. Indonesia di Persipangan Jalan. Pajar Sodik,

Jakarta . 1978. Fiqhud Dakwah. Bina Dakwah, Jakarta. . 1988. Kebudayaan Islam dalam Perspektif Sejarah, Giri

Mukti. 
2001 Agama dan Negara Dalam Perspektif Islam,

Media Da'wah, Jakarta 1984. Indonesia di Persimpangan Jalan, PT. Abadi, Jakarta, 1979;Pemikiran Dr. Mubammad Iqbal tentang Politik. dan Agama, Mutiara, Jakarta, 2001. Agama dan Negara: Dalam Perspektif Islam. Media Dakwah, Jakarta.

Natsir Zubaidi. 2012.Memaknai Islam Indonesia. Media Dakwah, Jakarta. Nurudin. 2007. Pengantar Komunikasi Massa. Rajawali Press, Jakarta.

Pawito. 2009. Komunikasi Politik: Media Massa dan Kampanye Pemilihan. Yogyakarta.

Remy Madinier. 2015. Partai Masjumi: Antara Godaan Demokrasi dan Islam Integral. Mizan, Bandung.

R. Z. Leirissa. 1997. PRRI Permesta: Strategi Membangun Indonesia Tanpa Komunis. Grafiti, Jakarta.

Seri Buku Tempo. 2001. Natsir: Politik Santun di Anatara Dua Rezim. KPG (Kepustakaan Populer Gramedia), Jakarta;

Tohir Luth. 1999. M. Natsir: Dawah dan Pemikiranya, Gema Insani Press, Jakarta.

Yusril Ihza Mahendra. 2006. Menyelamatkan NKRI: Berkaca pada Peran Syafroeddin Prawiranegara dan Mohammad Natsir. Jurnal Negarawan, Jakarta. 1999. Modernisme dan Fundamentalisme dalam Politik Islam. Paramadina, Jakarta. 
Roni Tabroni 